\title{
EFFECT OF SOME NATURAL ADDITIVES SUPPLEMENTED TO SUGAR SYRUP OF HONEYBEE ON CHEMICAL COMPOSITION AND NUTRITIONAL VALUES OF PRODUCED HONEY
}

Salama, A. A.

Food Technology Dept., Fac. of Agric., Kafr El-Sheikh Univ. Egypt.

\begin{abstract}
The present investigation was aimed to study the effect of some natural additives (yeast, soybean flour and milk whey) to sugar syrup of honeybee on chemical composition, nutritional values and orgaroleptic properties of produced honeys comparing with clover honey (control). The results indicated that; Soybean flour honey contained the lowest percentage of moisture $(13.82 \%)$ comparable with the other produced honeys. Control honey contained the highest moisture content (14.84\%). The total soluble solids (T.S.S.) of all tested honey were present in high percentage. Soybean flour honey contained the highest percentage of T.S.S. $(86.18 \%)$ followed by milk whey honey $(85.71 \%)$. Control honey contained the lowest T.S.S. $(85.16 \%)$. Total carbohydrates play the main role in the characteristics of all types of produced honey. Milk whey honey contained the highest value of total carbohydrates $(83.90 \%)$ followed by soybean flour honey $(83.54 \%)$, while control honey contained the lowest levels of total carbohydrates (83.18\%).

Yeast honey showed the lowest level of $\mathrm{pH}$ value (3.90) because it contain more levels of free acid, lactone and total acidity than that of other produced honeys. Fructose and glucose are the main sugars present in all analyzed honeys. Yeast honey contained the highest percentage of fructose $(40.20 \%)$, followed by milk whey honey $(39.40 \%)$ than these of soybean flour honey $38.50 \%$ and control honey $(38.10 \%)$. Soybean flour and control honeys seem to be more prone to granulate which contain slightly low amount of fructose/glucose. All produced honeys contained an excellent fructose/glucose ratios, especially yeast and milk whey honeys.

Honeys are good source of minerals. Yeast and milk whey honeys contained the highest amounts of $\mathrm{K}, \mathrm{Ca}, \mathrm{Mg}, \mathrm{Na}$ and $\mathrm{Fe}$.

The nutritional value of produced clover honeys were high because it contain noticeable amount of indispensable amino acids such as isoleucine, leucine, valine, lysine and theronine and contain dispensable amino acids such as proline, aspartic, glutamic and serine comparing with control honey. The results revealed that yeast and milk whey honeys had the best organoleptic qualities and accepted more by the paneltists comparing with soybean flour and control honeys.

Finally, the natural additives supplemented to sugar syrup as feeding of honeybee lead to improve the all properties and quality of produced honeys.
\end{abstract}

\section{INTRODUCTION}

Honey is natural food product having a high nutritional and prophylactic-medicinal value (Al-Mamary et al., 2002). The composition of honey is variable, owing to difference's in plant type, climate, environmental conditions and contribution of the beekeepers (Azeredo, et al. 2003). 
From analytical chemical points of view, honey is referred to as a complex matrix, which consists mostly of a mixture of carbohydrates (e.g. glucose, fructose, maltose, sucrose) and several other substances, such as traces of other sugars, organic acids, enzymes, amino acids, pigments, pollen and waxes. (Bogdanov, et al. 1999 and al-Mamery, et al. 2002). Owon and Shawer (1998) studied the influence of sugar syrup which used in honeybees feeding at concentration of $70 \%$ on the flavour compounds of produced honeys. The concentration of flavour compounds were increased with increasing the amount of sugar syrup, which used by honeybees.

Sayed Ahmed (1997) found that dispensable amino acids were increased by the decreasing of sugar syrup which used for feeding honeybees, while the natural honey protein contained low amount of dispensable amino acids than the other analyzed honeys. The results showed that sucrose honey gave better quality than fructose honey. The values of colour and flavour (taste and odour) increased by the decrease of the used sucrose or fructose sugar syrup.

Determination of moisture, acidity, total and reducing sugars, sucrose, protein, $\mathrm{K}$ and $\mathrm{Na}$ content, proline content and total pollen spectrum were important in determining whether honey is natural or being produced by over feeding of bees with sucrose. (Basoglu, et al. 1996).

Pourtaltier and Rognone (1990) reported the trails in which the ranges of detection were: glucose, 0-70 g; fructose, 0-90; sucrose, 0-40 gm. The main amino acids found in 31 honeys of five different botanical origins were proline, phenylalanine, tyrosine and lysine. (Hermosin, et al. 2003). Malacalza et al. (2001) found that the ash values in samples of honey varied between 0.004 and $0.236 \%$.

Honey is popularly used in Egypt since acient times. Its utilization in caring many diseases is well established (Russo et al., 2002). There is an increasing interest in the use of honey for the treatment of bacterial infections (Molan et al. 1988). All honey types possess stronger anitmicrobial activity (Owon, 2004 and Sheref, 2007).

Consumption of honey show considerable increases in recent years. The population reduced the refined sugar composition and people seem to be more a ware of honey.

The present work was directed to study the effect of some natural additives supplemented to sugar syrup of honeybee on the chemical composition and nutritional values of produced honeys.

\section{MATERIALS AND METHODS}

The present work was conducted at the Apiary of Faculty of Agriculture in Kafr El-Sheikh, during the blooming period of clover throughout two successive seasons (from $1^{\text {st }}$ January 2003 till the end of April, 2005). All colonies were approximately equal in strength and number of combs covered with bees and sufficient food. The experiment was conducted to find out the effect of some natural additives such as wet yeast, soybean flour and milk whey on certain aspects on honeybee activities, chemical composition and nutritional values of clover honeys samples. 
Twenty colonies were chosen to carry on this work. The number of the chosen colonies were divided into four treatments, so each treatment was represented by five colonies.

The following natural additives were supplemented to the sugar syrup used for honeybee feeding. Each additive was mixed with three liters of sugar syrup and used for feeding five honeybee colonies. The supplemented was done as follows :

1- 50 gram of wet yeast and three liters of sugar syrup, the produced honey was named yeast honey.

2- One kilo gram of soybean flour and three liters of sugar syrup, the produced honey was named soybean flour honey.

3- Three liters of milk whey and three liters of sugar syrup, the produced honey was named milk whey honey.

4- Control, (without additives) 3 liters of water were supplemented to 3 liters of sugar syrup, the produced honey was named control honey .

Produced honey samples were collected from Apiary of Faculty of Agriculture in Kafr El-Sheikh. One kg of each type of honeys were placed in glass jars and transferred to laboratory of food Tech., Fac. of Agric. in Kafr Elsheikh. The samples were kept at room temperature $\left(25^{\circ} \mathrm{C}\right)$ until analysis.

\section{Chemical composition of produced honeys :}

Moisture content of the four types of produced honeys were determined using the values of refractive index at $20 \mathrm{C}^{\circ}$. Protein, ash, reducing sugars and higher sugars were also determined according to the methods of A.O.A.C. (1990).

Minerals such as potassium $(\mathrm{K})$, sodium $(\mathrm{Na})$, calcium $(\mathrm{Ca})$, magnesium $(\mathrm{Mg})$, iron, $(\mathrm{Fe})$, copper $(\mathrm{Cu})$, zinc $(\mathrm{Zn})$, cadmium $(\mathrm{Cd})$ and manganese $(\mathrm{Mn})$ were detected in the ashed materials using the atomic absorption spectrophotometer (Perken Elmer Model 2180) as outlined by Pearson (1976).

The amino acids composition of different types of produced honeys were determined after acid hydrolysis ( $\mathrm{HCL} 6 \mathrm{~N}$ ) according to the method described by Pellet and Young (1980) using Backman Amino Acid Analyzer (Model $119 \mathrm{CL}$ ) at central laboratory, Fac. of Agric., Alex., Univ. Egypt.

Total soluble solids (T.S.S.) were measured by means of an Abbe refractometer with the correction of the temperature variation according to A.O.A.C. (1990).

Acidity, free acidity and lactone content were determined by White et al. (1962). The values were examined using glass rod pH-meter (Unicam-pH meter Pw 8410 digital pH meter).

\section{Organoleptic properties of produced Honeys :}

Organoleptic properties of the Honeys were carried out according to the method reported by Molander (1960) by twenty panalests. The scores were recorded according to the following judging scale: Very good (8-9), Good (6-7), Fair (4-5), Poor (2-3) and very poor (0-3). 


\section{RESULTS AND DISCUSSION}

\section{Chemical properties of produced honeys :}

The composition of honey is variable, owing to deference's in plant type, climate, environmental conditions, feeding sugar syrup and contribution of the beekeepers, (Azeredo, et al. 2003). The quality of honey is mainly determined by its sensorial, chemical and physical parameters, comprising moisture content, sugars, minerals, acidity and water insoluble solids content. The results in Table (1) represent the effect of some natural additives (yeast, soybean flour and milk whey) supplemented to feeding sugar syrup of honeybee on the chemical properties of clover honey samples. Moisture is one of the most important characteristics of honey influence keeping quality, granulation and body (White, 1975). The results cleared that soybean flour honey contained the lowest percentage of moisture (13.82\%) compared with those of other produced honeys. Control honey contained the highest level of moisture (14.84\%).

It is well known that honey with high water content is readily susceptible to fermentation by osmophilic yeast. Yeast fermentation may be negligible when water content is less than $17.1 \%$, while between 17.10 and $20.0 \%$, fermentation depends on the count of osmophilic yeast buds (Beltz and Grosch, 1987). None of the investigated honeys showed such high moisture content (Table 1). The total soluble solids (T.S.S.) of all tested honeys were present in high percentage. Soybean flour honey contained the highest percentage of T.S.S. (86.18\%) followed by milk whey honey $(85.71 \%)$ and the lowest content of T.S.S., was detected in control honey $(85.16 \%)$. These results may indicated an overall better quality of produced honeys.

Carbohydrates play the main role in the characterization of all types of produced honeys. Data in Table (1) showed that milk whey honey contained the highest content of total carbohydrates $(83.90 \%)$, followed by soybean flour $(83.54 \%)$, while control honey contained the lowest levels of total carbohydrates (83.18\%).

The presence of proteins causes honey to have a lower surface tension than it would have otherwise, which produces a marked tendency to foam and form scum and encourages formation of fine air bublles (White, 1975). The results indicated that the average levels of protein were increased in the produced honeys. Soybean flour honey contained the highest percentage of protein $(1.48 \%)$ followed by control honey $(1.12 \%)$, while yeast honey contained the lowest amount of protein $(0.96 \%)$. These values are higher than those reported by Beltz and Grosch (1987) and Gomez et al. (1993).

The results in Table (1) show that ash content was increased in yeast and milk whey honeys, which recorded 1.20 and $0.91 \%$, respectively, while control honey contained $0.86 \%$. On the other hand, soybeam flour honey recorded the lowest percentage of ash $(0.80 \%)$. From the data in Table (1), it could be summarized that there were clear differences in $\mathrm{pH}$ values among the tested honey samples. Yeast honey showed the lowest pH value (3.90) followed by soybean flour honey (4.20). These results indicated that samples with high $\mathrm{pH}$ values had high ash and minerals contents. The highest $\mathrm{pH}$ 
value was recorded in milk whey honey (4.50), however all tested honey samples were accepted by the Egyptian Standard (Anon. 2003). Parameters for acidity was used to determine the degree of deterioration of the honey during storage. The lactone is a newly component detected in honey. Lactones may be considered as a reserve acidity, since hydrolysis is occurred and an acid is formed (White, 1979). The acidity in honey contributes not only to the flavour, but also partially responsible for the excellent stability of honey against microorganisms (White and Subers, 1963).

Table (1): Effect of some natural additives supplemented to sugar syrup of honeybee on the chemical characterization of produced honeys (based on wet weight).

\begin{tabular}{|l|r|r|r|c|}
\hline \multirow{2}{*}{ Constituents } & \multicolumn{4}{|c|}{ Produced honeys } \\
\cline { 2 - 5 } & Control & Yeast & $\begin{array}{c}\text { Soybean } \\
\text { flour }\end{array}$ & Milk whey \\
\hline Moisture \% & 14.84 & 14.33 & 13.82 & 14.29 \\
\hline T.S.S. \% & 85.16 & 85.67 & 86.18 & 85.71 \\
\hline Total carbohydrate \% & 83.18 & 83.51 & 83.54 & 83.90 \\
\hline Protein \% & 1.12 & 0.96 & 1.48 & 1.26 \\
\hline Ash \% & 0.86 & 1.20 & 0.80 & 0.91 \\
\hline pH & 4.00 & 3.90 & 4.20 & 4.50 \\
\hline Free acidity $(\mathrm{meq} / \mathrm{kg})$ & 30.10 & 31.60 & 30.20 & 29.90 \\
\hline Lactone $(\mathrm{meq} / \mathrm{kg})$ & 3.70 & 5.40 & 4.80 & 5.20 \\
\hline Total acidity $(\mathrm{meq} / \mathrm{kg})$ & 33.80 & 37.00 & 35.00 & 35.10 \\
\hline
\end{tabular}

The results in Table (1) indicated that yeast honey contained more free acids, lactone and total acidity than those of all analyzed honeys. Milk whey honey showed considerably highest content of lactone $(5.20 \mathrm{meq} / \mathrm{kg})$, while control honey had lower amount of lactone $(3.70 \mathrm{meq} / \mathrm{kg})$. The results obtained in Table (1) indicated that, each kind of honey has a characteristic chemical composition, which could be used for its identification. Many authors discussed the chemical properties of the honey and they found that, $\mathrm{pH}$ values in Egyptian honeys were ranged between by 4.0-4.4 (Ibrahim et al. 1977).

\section{Sugar analysis of produced honeys}

Effect of some natural additives supplemented to sugar syrup of honeybee on mono-di and higher sugar of clover honey were presented in Table (2). The HPLC analysis of honey carbohydrates indicated that the investigated honeys contained many kinds of mono and oligosaccharides, which were found to play a great role in both the taste and also the nutritional values of these honeys. Fructose and glucose are the main sugars present in all analyzed honeys. Yeast honey contained the highest percentage of fructose $(40.20 \%)$, followed by milk whey honey $(39.40 \%)$ than that of soybean flour honey $(38.50 \%)$ and control honey $(38.10 \%)$. On the other hand, control honey had the highest level of glucose $(32.0 \%)$ while the lowest amount of glucose was detected in yeast honey (29.50\%). The present results confirm those reported by Al-Khalifa and Al-Arify (1999) since they reported that fructose and glucose are the predominant sugars in honey. The 
Sălama, A. A.

sugar analysis indicated that fructose and glucose contents are similar to those reported by Gomez et al. (1993) for Spanish honeys. Maltose was the main disaccharide in all investigated honeys, which recorded between $6.65 \%$ in soybean flour honey and $6.22 \%$ in control honey. Sucrose was found relatively in smaller percentage, especially in yeast and milk whey honeys, which recorded 1.90 and $2.10 \%$, respectively.

Table (2): Effect of some natural additives supplemented to sugar syrup of honeybee on some sugars of produced honeys (based on wet weight).

\begin{tabular}{|l|r|r|r|c|}
\hline \multirow{2}{*}{$\begin{array}{c}\text { Sugars } \\
(\%)\end{array}$} & \multicolumn{4}{|c|}{ Produced honeys } \\
\cline { 2 - 5 } & Control & Yeast & $\begin{array}{c}\text { Soybean } \\
\text { flour }\end{array}$ & Milk whey \\
\hline Fructose & 38.10 & 40.20 & 38.50 & 39.40 \\
\hline Glucose & 32.00 & 29.50 & 30.70 & 29.80 \\
\hline Sucrose & 2.80 & 1.90 & 2.85 & 2.10 \\
\hline Maltose & 6.22 & 6.68 & 6.65 & 6.07 \\
\hline Higher sugars & 4.06 & 5.23 & 4.84 & 6.53 \\
\hline Fructose/glucose & 1.19 & 1.36 & 1.25 & 1.32 \\
\hline Glucose/water & 2.16 & 2.06 & 2.22 & 2.09 \\
\hline
\end{tabular}

The lowest amount of other higher sugars was found in control honey, followed by soybean flour honey, while the highest amounts of these sugars were detected in milk whey honey (6.53\%). Fructose/glucose and glucose/water ratios were a good indicator for granulation of honeys. All produced honey contained an excellent fructose/glucose ratios, especially yeast and milk whey honeys.

\section{Minerals content of produced honeys :}

Mineral content is known to be one of the main factors affecting the colour of honey (Mattos et al. 1998). Among the minerals, potassium appeared in the greatest proportion followed by sodium, magnesium and calcium (Table 3). Most of honey samples under investigation were found to be contained high amount of iron, especially yeast and milk whey honeys, which contained 2.93 and $2.85 \mathrm{mg} / 100 \mathrm{~g}$, respectively. Zinc was found in lowest amount among all minerals, which ranged between 0.26 in yeast honey to $0.10 \mathrm{mg} / 100 \mathrm{~g}$ in milk whey honey. Yeast honey contained the highest amounts of potassium, calcium, magnesium and sodium, while soybean flour honey recorded the lowest of these minerals.

It could be concluded that the produced honeys were effected by additive supplemented to sugar syrup, which increased the most of minerals. The data in Table (3) indicate that honeys are good source of minerals, especially potassium, sodium magnesium, calcium and iron. These results are similar to those reported by Badei and Shawer (1990) and Mattos et al. (1998). 
Table (3): Effect of some natural additives supplemented to sugar syrup of honeybee on minerals content of produced honeys ( $\mathrm{mg} / \mathbf{1 0 0 \mathrm { g }}$ of honey).

\begin{tabular}{|l|c|c|c|c|}
\hline \multirow{2}{*}{ Minerals } & \multicolumn{4}{|c|}{ Produced honeys } \\
\cline { 2 - 5 } & Control & Yeast & $\begin{array}{c}\text { Soybean } \\
\text { flour }\end{array}$ & Milk whey \\
\hline Potassium (K) & 9.05 & 10.10 & 8.83 & 9.54 \\
\hline Calcium (Ca) & 5.19 & 6.18 & 5.10 & 5.50 \\
\hline Magnesium (Mg) & 6.80 & 6.95 & 6.70 & 5.82 \\
\hline Sodium (Na) & 8.15 & 8.83 & 7.32 & 8.61 \\
\hline Iron (Fe) & 1.72 & 2.93 & 1.70 & 2.85 \\
\hline Copper (Cu) & 0.87 & 0.72 & 0.45 & 0.63 \\
\hline Zinc (Zn) & 0.22 & 0.26 & 0.09 & 0.10 \\
\hline Manganese (Mn) & 0.96 & 0.70 & 0.40 & 0.61 \\
\hline
\end{tabular}

Amino acids content of produced honeys :

The results in Table (1) show that feeding processes increased the protein, especially soybean flour honey. Amino acids composition of the four investigated honeys are given in Table (4). The detected indispensable amino acids in soybean flour and yeast honeys recorded the highest total values 15.68 and 15.57 ( $\mathrm{g} / 100 \mathrm{~g}$ protein), respectively, while the lowest value was observed in control honey (10.61 $\mathrm{g} / 100 \mathrm{~g}$ protein).

Isoleucine was the predominant among the indispensable amino acids in all investigated honeys, followed by valine and leucine. Generally, the data in Table (4) revealed that all four honeys contained the same indispensable amino acids but its amount varied greatly according to the type of additives. Soybean flour honey contained high values of isoleucine, valine, leucine, phenylalanine, thrionine and lysine. Yeast honey contained higher amounts of lysine, methionine and phenylalanine than those of other analysed honeys. Milk whey honey contained low amount of indispensable amino acids comparing to soybean flour and yeast honeys, control honey recorded the lowest levels of indispensable amino acids ( $10.61 \mathrm{~g} / 100 \mathrm{~g}$ protein). The data in Table (4) cleared that the produced honeys had high nutritional value because it contain all of indispensable amino acids, which suggests that honey will markedly contribute to the supply of indispensable amino acids in human diet.

On the other hand, the results indicate that proline was the major dispensable amino acids present in all investigated honey proteins. The concentration of proline was ranged between 9.68 and 7.60 (g/100 g protein) in milk whey and control honeys, respectively. The analyzed honeys contained high amounts of aspartic, glutamic acids, serine and arginine. The results indicated that feeding processes increased most of dispensable amino acids. The total dispensable amino acids were higher in soybean flour honey (25.43), milk whey honey (25.12) and yeast honey (22.64) than those in control honey ( $20.78 \mathrm{~g} / 100 \mathrm{~g}$ protein).

These results are similar to those obtained by Campus et al. (1993) and Gomez et al. (1993). Cystine is the limiting amino acid in all studied honeys. Tyrosine was found the second limiting amino acid, especially in milk 
Sădàma, A. A.

whey honey. The obtained results were in agreement with those recorded by Owon (2004).

Table(4):Amino acids composition of produced honeys ( $\mathrm{g} / 100 \mathrm{~g}$ protein).

\begin{tabular}{|c|c|c|c|c|}
\hline \multirow{2}{*}{$\begin{array}{c}\text { Amino acids } \\
\text { (A.A.) }\end{array}$} & \multicolumn{4}{|c|}{ Produced honeys } \\
\hline & Control & Yeast & Soybean flour & Milk whey \\
\hline \multicolumn{5}{|l|}{ Indispensable A.A.: } \\
\hline Lysine & 1.29 & 1.88 & 1.33 & 1.80 \\
\hline Thereonine & 1.20 & 1.18 & 1.30 & 1.43 \\
\hline Methionine & 0.49 & 0.89 & 0.80 & 0.65 \\
\hline Cystine & 0.19 & 0.09 & 0.18 & 0.07 \\
\hline Pheylalanine & 1.30 & 1.75 & 1.56 & 1.46 \\
\hline Tyrosine & 0.46 & 0.63 & 1.66 & 0.29 \\
\hline Isoleucine & 2.27 & 3.48 & 3.94 & 2.70 \\
\hline Leucine & 1.77 & 3.12 & 1.92 & 2.50 \\
\hline Valine & 1.64 & 2.55 & 2.99 & 2.39 \\
\hline Total indispensible A.A. & 10.61 & 15.57 & 15.68 & 13.29 \\
\hline \multicolumn{5}{|l|}{ Dispensable A.A. } \\
\hline Aspartic acid & 4.57 & 5.74 & 5.67 & 5.01 \\
\hline Serine & 1.71 & 1.15 & 2.85 & 1.24 \\
\hline Glutamic acid & 2.80 & 3.01 & 3.47 & 3.61 \\
\hline Proline & 7.60 & 7.69 & 8.47 & 9.68 \\
\hline Glycine & 1.09 & 1.41 & 1.15 & 1.56 \\
\hline Alanine & 1.02 & 1.47 & 1.14 & 1.63 \\
\hline Histidine & 1.08 & 1.16 & 0.96 & 1.29 \\
\hline Arginine & 0.91 & 1.01 & 1.72 & 1.10 \\
\hline Total dispensable A.A. & 20.78 & 22.64 & 25.43 & 25.12 \\
\hline Total amino acids & 31.39 & 38.21 & 41.11 & 38.41 \\
\hline
\end{tabular}

\section{Organoleptic qualities of produced honeys :}

The intrinsic changes in honey quality were classified into five categories according to the total scores of their organoleptic qualities. These categories were very good, good, accepted, poor and very poor. Investigated honey samples show that all produced honeys were free from any insect fragments, samd particles, undesirable flavour and any fermentation. As shown in Table (5) the panel test judgment of produced honeys refereed to their colour, taste, odour, viscosity, sourness and general appearance. The results reveal that yeast and milk whey honeys had the best qualities comparing with soybean flour and control honeys. The mean values flavour (taste and odour) of yeast and milk whey honey were higher than soybean flour and control honeys. Control honey was characterized by very good colour than all other honeys. soybean flour honey recorded the lowest colour, while milk whey honey was recorded the lowest viscosity (Table 5).

On the other hand, milk whey honey was contained the highest sourness, while other honey samples contained the same sourness and viscosity. Yeast honey showed better results than both of milk whey and soybean flour honeys and accepted more by the panelistis, which may be 
due to the pleasant flavour. The obtained results were in agreement with those obtained by Owon (2004).

Table (5): Effect of some natural additives supplemented to sugar syrup of honeybee on the organoleptic properties of produced honeys.

\begin{tabular}{|l|c|c|c|c|}
\hline \multirow{2}{*}{ Minerals } & \multicolumn{4}{c|}{ Produced honeys } \\
\cline { 2 - 5 } & Control & Yeast & Soybean flour & Milk whey \\
\hline Colour & 9 & 8 & 7 & 8 \\
\hline Taste & 7 & 9 & 7 & 9 \\
\hline Odour & 7 & 8 & 7 & 8 \\
\hline Viscosity & 8 & 8 & 8 & 7 \\
\hline Sourness & 7 & 7 & 7 & 8 \\
\hline General appearance & 8 & 9 & 8 & 9 \\
\hline
\end{tabular}

\section{ACKNOWLEDGEMENT}

The feeding experiments of honeybee colonies at the Apiary of faculty of Agric. Kafr El-Sheikh and collecting of produced honey samples used in this research was designed and carried out kindly under the supervision of Prof. Dr. Helal, R.M. Prof. of Economic Entomology, Economic Entomology Dep., Fac. of Agric., Kafr El-Sheikh Univ., I would like to express my deep appreciation to him.

\section{REFERENCES}

Al-Khalifa, A.S. and Al-Arify, I.A. (1999). Physicochemical characteristics and pollen spectrum of some Saudi honeys. Food Chemistry, 67: 21-25.

Al-Mamary, M.; Al-Mmeeri, A. and Al-Habori, M. (2002). Antioxidant activities and total phenolics of different types of honey. Nutrition Research, 22: 1041-1047.

Anonymous (2003). Egyptian Standard honey an Methods of test and experiment chapter one: Honey. Egyptian organization for Standardization Unification and Production quality.

A.O.A.C. (1990). "Official Methods of Analysis". 13 th ed.; Association of Official Analytical Chemists, Washington, D.C. U.S.A.

Azeredo, L.C.; Azeredo, M.A.; Souza, S.R. and Dutra, V.M. (2003). Protein contents and physicochemical properties in honey samples of Apis mellifera of different floral origins. Food Chemistry, 80: 249-254.

Badei, A.Z.M. and Shawer, M.B. (1990). Retardation of honey granulation by heat treatment. Egyptian Journal of Food Science, 18 (3): 221-231.

Basoglu, F.; Sorkun, K.M.; Loker; Dogan, C. and Wetheriit, H. (1996). Physical, chemical and pollen properties of honey. Gida, 21 (2): 67-73.

Beltz, H.D. and Grosch, W. (1987). Food Chemistry; translation from $2^{\text {nd }}$ German Edition by Hadziyev, D.; Springer-Verlag: Berlin; pp 644-680.

Bogdanov, S.; Lu..liman, C.; Martin, P.; Von Der Ohe, (1999). Honey quality and international regulatory standards: review by the international honey commission. Bee World, 80 (22): 61-69. 
Campus, R. Madav, G.; Salia, B. (1993). La composione dei mieli sardi: nota sul contenuto in sos tanze polifeno liche. Technolotgie Alimentari 6 (10): 10-15.

Gomez, M.E.; Hernandez, E.G.; Gomez, J.Y. and Marin, J.L. (1993). Physicochemical analysis of Spanish Commercial Eucalyptus honeys. J. of Apic. Res. 32 (3/4): 121-126.

Ibrahim, S.H.; Soliman, N.Z. and Wissa, H. (1977). Studies on the properties of the major Egyptian honey types and on honey ripening. Agric. Res. Rev., 55: 125-129.

Malacalza, N.H.; Mouteira, M.C.; Baldi, B.M. and Lupano, C.E. (2001). Characterization of honey of different zones of the province o Buenos Aires, Argentine, Proc. $37^{\text {th }}$ Int. Apic. Congr., Durban, South Africa.

Mattos, S.V.M.; Bastos, E.M. Dayrell, I.O. and Nelson, D.L. (1998). Correlation between $\mathrm{K} ., \mathrm{Mn}, \mathrm{Fe}, \mathrm{Cu}$ and $\mathrm{Zn}$ in natural honeys from Eucalyptus sources. Brazilianarchives of Biology and Technology, 41:1, 170-178.

Molan, P.C.; Smith, I.M. and Reid, G.M. (1988). A comparison of the antibacterial activities of some New Zealand honeys. J. Agric. Research 27 (4): 252-256.

Molander, A.L. (1960). Discernment of primary taste substance and probable ability to Judge Food. Lowa State Univ. Press, Ames, lowa USA.

Owon and Shawer (1998). Effect of feeding sugar syrup to honeybees colonies on the flavour compounds of produced honeys. J. Agric. Sci. Mansoura Univ., 23 (5): 2071-2083.

Owon, M.A. (2004). Comparative studies on some Egyptian Honeys. J. Agric. Res. Tanta Univ., 30 (3): 661-675.

Pearson, D. (1976). The chemical analysis of foods. $7^{\text {th }}$ Ed. Churchill, London, U.K.

Pellet, R.KL. and Young, V.Q. (1980). Nutritional evaluation of protein foods. Food and Nutrition bulletin, supplemental. Published by the United Nations University.

Pourtaltier, J.E. and Rognone, D. (1990). A new method for the analysis of honey sugars by high performance liquid chromatography. Abeille de France. Et. J. Apiculteur, 754: 448-451.

Russo, A.; Longo, R.; Vanella, A.; Borrelli, F.; Izzo, A.A. (2002). Antioxidant activity of propolis: role of caffeic acid phenethyl ester and galangin. Propolis: Chemical and pharmacological aspects, Naples, Italy, February, 24.

Sayed-Ahmed, Amal B. (1997). Some factors affecting the production of honeybee colonies. M.Sc. Thesis, Fac. of Agric., Kafr El-Sheikh, Tanta Univ., Egypt.

Sheref, A.S.F. (2007). Studies on Egyptian Honey. Ph. D. Fac. Agric. Economic Entomology, Dept. Kafr el-Sheikh University.

White, J.W.; M.L. Reithof, M.H.; Sueers and Kushnir, J. (1962). Composition of American Honeys. Tech. Bull. USDA, 1261.

White, J.W. and Subers, M.H. (1963). Studies on honey inhibine 2. A chemical assay. J. Apic. Res. $2: 93-100$. 
White, J.W. (1975). Composition of honey. In Crane, E. (ed) Honey, a comprehensive survey. Heinemann; London, UK; PP. 157-206 (2 ${ }^{\text {nd }}$ Ed.).

White, J.W. and Rudyj, O.N. (1978). The protein content of honey. J. Apic. Res. 17 (4): 234-238.

White, J.W. (1979). Composition of honey. In Honey: A comprehensive survey; Crane, E., (ed.); Heinemann in Cooperation with International Bee Research Association: London.

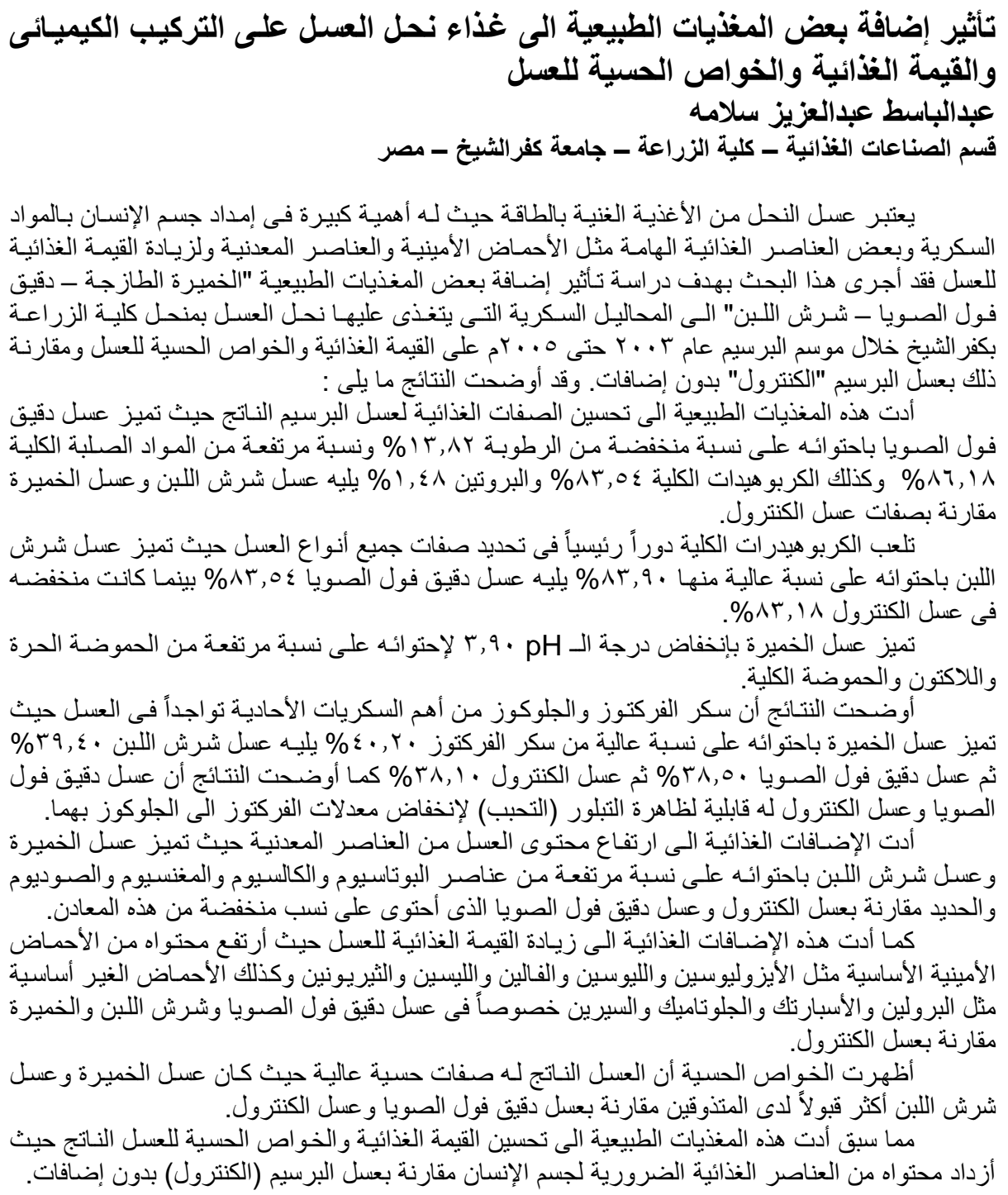

